This article was published in Israel Studies, 24(3), 126-156. https://doi.org/10.2979/israelstudies.24.3.06. No part of this article may be reproduced, stored in a retrieval system, transmitted, or distributed, in any form, by any means, electronic, mechanical, photographic, or otherwise, without the prior permission of Indiana University Press. For re- use, please contact the Copyright Clearance Center (www.copyright.com, 508-744-3350). For all other permissions, please visit http://iupress.org.

\title{
Israel-PLO Peace Process: Interview with Ambassador Daniel Kurtzer ${ }^{1}$ Raphael Cohen-Almagor
}

\section{Introduction}

Over the past few years, I have been researching the failed peace process between Israel and the PLO, from Oslo 1993 until the present. I have examined how the conditions of peace were advanced and promoted via thirdparty mediation. This research is important, as the Americans continue to fail in their mediation attempts. Indeed, the Oslo channel was opened at a time when formal, non-secretive negotiations between Israel and the Palestinians were stalled in Washington DC. To date, despite considerable political, economic and diplomatic investments in the peace process, the United States has been unable to bring the Israelis and the Palestinians to sign a comprehensive peace pact and to settle their bloody conflict. While some progress has been made, peace is still a distant prospect.

The goal of the Kurtzer interview is to unearth the historical processes constituting the peace process from an American perspective. Evidence from people who were part of the process can help identify the factors that move history forward. The interviews I conducted with Kurtzer and some thirty other people reveal that there is not one history, but many histories. People who were in the same room perceive the same situation in different ways. A classic Rashomon.

The Kurtzer interview begins with Oslo 1993. The Intifada, which erupted in 1987, constituted a threat to Arafat's leadership. ${ }^{3}$ He was surprised

1 This interview is taken from my book, From Oslo to Jerusalem: A Critical Study of Peace Mediation, Facilitation and Negotiations between Israel and the PLO (Cambridge, forthcoming).

${ }^{2}$ I thank Tzippy Hauser for her constructive comments and kind assistance.

3 Mary Elizabeth King, A Quiet Revolution: The First Palestinian Intifada and Nonviolent Resistance (New York, 2007); Raphael Cohen-Almagor, "The Intifada: Causes, Consequences, and Future Trends", Small Wars \& Insurgencies, 2(1) (1991): 12-40. 
by the scale of the uprising, which brought thousands of protesters to the streets to fight against the Israeli occupation. The rise of Hamas further threatened his position in Gaza and the West Bank. Arafat was anxious to do something which would bring him to the center of attention. Moreover, his alliance with the Iraqi dictator Saddam Hussein during the 1991 Gulf War undermined his position in the moderate Arab world. Arafat needed to reinforce his leadership among the Palestinian people.

Arafat was also well aware of the warming relationship between Israel and Jordan. ${ }^{4} \mathrm{He}$ understood that King Hussein was interested in signing a peace treaty with Israel. Egypt had signed a peace treaty with Israel without the Palestinians, and Arafat had no illusions that Hussein would insist on waiting for him, or would coordinate steps leading to peace with him. He thought another peace pact between Israel and an Arab country would further isolate him.

The collapse of the Soviet Union during the late 1980s, as a result of the Cold War, the arms race, technological deficiency, the rise of the Soviet national republics, and the inner power struggle in Moscow, left the international arena with only one powerful actor, the United States, which squarely aligned itself with Israel. ${ }^{5}$ Arafat could no longer count on the Soviet Union to serve as a counterbalance against American interests. $\mathrm{He}$ understood the need to create new opportunities for himself, inter alia, by establishing ties with the West and, especially, the United States.

The return of Israel's Labour Party to power in the summer of 1992 signalled a moment of change. In his second term as prime minister, the more experienced Yitzhak Rabin wished to move away from containment to signing peace treaties with Israel's neighbours, first and foremost Syria. He was also prepared to address the core of the Israeli-Palestinian conflict: the occupation. His foreign minister, Shimon Peres, explained that "We were not going to rule the Palestinians against their will. We were always looking for a way to liberate them from our occupation and to liberate ourselves as occupiers". ${ }^{6}$

At the time, negotiations with the Palestinian Liberation Organization (PLO) were illegal for Israelis, as it was deemed a terrorist organization. The Israeli government refused to officially negotiate with Arafat, although it was clear that he was still the person most capable of striking a deal, and the only true representative of the Palestinian people. Bilateral negotiations had begun in Washington between Israel and Palestinians who were supposedly independent of the PLO, although everyone knew they were not. As mentioned above, these talks led nowhere. ${ }^{7}$

In his 29-year career in the U.S. Foreign Service, Daniel Kurtzer served as the United States Ambassador to Israel (2001-2005) and to Egypt (19972001). Kurtzer is presently the S. Daniel Abraham Professor of Middle East Policy Studies at the Woodrow Wilson School of Public and International Affairs, Princeton University, and he has published important books about the

\footnotetext{
${ }^{4}$ Shabtai Shavit, Head of Mossad (Rishon LeZion, 2018), 167-190 [Hebrew]. Interview with Shavit (July 2, 2018).

${ }^{5}$ David R. Marples, The Collapse of the Soviet Union, 1985-1991 (London, 2004).

6 Shimon Peres and Robert Littell, For the Future of Israel (Baltimore, 1998): 83.

7 lbid., 84.
} 
peace process. For the purpose of my own book, Kurtzer granted me a long interview. Here, I bring his thoughts about Oslo, Camp David, Taba, the Arab peace initiative, and Hamas.

\section{Interview with Ambassador Daniel Kurtzer:}

April 6, 2017

Princeton, N.J.

Cohen-Almagor: When did you hear the word "Oslo", and "Oslo Accords" for the first time?

Kurtzer: I was actually the first American official to be aware that anything was brewing. It was the summer of 1992, when the then-Deputy Foreign Minister of Norway, Jan Egeland, came to Washington for a visit. I was invited to lunch at the home of the Norwegian Ambassador, and when the lunch finished, Mr. Egeland and the Ambassador asked if I would stay behind. I did, and they said, "How would the American administration react if we, the Norwegians, tried to develop some kind of a dialogue between Israel and the PLO?" My response was to say three things. Number one, if you want an official American government viewpoint, l'll take the question back to the State Department, and work it through the system to get an answer for you. Number two, if you want my personal view, there's no reason for you to ask us. You're an independent country, and if Israel and the PLO want to start a dialogue that's fine. But I would hope that you would keep us deeply informed of what you do, so that we, as the shepherd of the Madrid peace process ${ }^{8}$ would not be caught unawares of what you were doing. And number three, I said, if you go ahead and do it, just a piece of advice. They had mentioned to me that this was a Shimon Peres, Yossi Beilin, Avi Gil' ${ }^{9}$ initiative. I said, don't do it unless you have Rabin on board. Because we've had experience, for example, the London Accord, back in 1987, where Peres tried something, but he did it behind the back of the sitting prime minister. ${ }^{10}$ You don't want that to happen here. So, if you go ahead and do it, you've got to make sure that there is a unified view within the Israeli government.

\footnotetext{
8 The Madrid Peace Conference, held from October 30 to November 1, 1991, was the first time that Israeli leaders negotiated face to face with delegations from Lebanon, Jordan, Syria, as well as with the Palestinians.

9 See Avi Gil, The Peres Formula (Modi'ín, 2018) [Hebrew].

10 The London Agreement between King Hussein of Jordan and Foreign Affairs Minister Shimon Peres was signed during a secret meeting held at the residence of Lord Mishcon in London on April 11, 1987.
} 
Cohen-Almagor: So, it's July '92? Around that time?

Kurtzer: $\quad$ Probably August, because it was after the Israeli election. The election was in June. I can't remember when Rabin actually formed the government. It was after the government was formed.

Cohen-Almagor: And then you continued to hear about it?

Kurtzer: I didn't hear anything for a few months, until December. During that period, the Knesset changed the law with regard to Israeli contact with the PLO. They changed the law, and decriminalized contact with the PLO. Around that time, I heard from Yair Hirschfeld, whom I had met when I was stationed in Israel in the 1980s. We had become friends. He called me and said that he was coming to London in January, on the margins of one of the multilateral negotiations that we were shepherding at the time. I was the U.S. official largely responsible for the multilaterals, so I was going to be in London. He said to me that they're going to have the first meeting in London with PLO representatives, organized by the Norwegians. After the meeting he briefed me.

Cohen-Almagor: He met Abu Ala ${ }^{11}$ and then he briefed you?

Kurtzer: $\quad$ Right, exactly. After the initial contact with Egeland, and after this meeting and all of the subsequent meetings that I was briefed on, I would send a note "outside the system". In other words, it was a note with restricted readership that would go to the Secretary of State and the peace team. The briefings I received were all memorialized. The reason I mention this is going to become important later. Nothing about Oslo should have been a surprise later, as some people thought it was. After their February meeting, which took place in Oslo, Hirschfeld called and shared with me the first draft of the Declaration of Principles ${ }^{12}$ that had been discussed, and I shared with him some of my own comments. This was not a cleared piece of paper on our side, but my own views. We were also discussing a declaration of principles in the formal negotiations in Washington, so this was all kind of coming together, or merging in some way. I don't think he was happy

\footnotetext{
11 Ahmed Qurei, known as Abu Ala, was born in the Abu Dis area in 1937. Qurei joined the PLO in the late 1960s and was an early member of Fatah. In 1989, he was elected to the Fatah Central Committee, specializing in economic affairs.

12 Declaration of Principles on Interim Self-Government Arrangements (September 13, 1993), http://www.mfa.gov.il/mfa/foreignpolicy/peace/guide/pages/declaration\%20of\%20principles. aspx
} 
with my comments. If you read his book,,$^{13}$ he thought I was too tough on what they were doing. Hirschfeld kept me informed after every meeting between January and May.

Cohen-Almagor: In what form? In phone calls or memos?

Kurtzer: $\quad$ Phone calls. At some point along the way, two other things happened.

In addition to Hirschfeld's briefings, twice Egeland went to the American Embassy in Oslo, and called me on the secure line. He gave a fairly detailed briefing of where things were in the talks. I wrote that up for the Secretary and the peace team. And then, the Foreign Minister of Norway called Secretary Christopher ${ }^{14}$ and briefed him. So, we were being kept pretty much informed by both the Israeli side and the Norwegian side. Primarily through me, but then we also had direct contact between the Norwegian Foreign Minister and the Secretary of State.

Cohen-Almagor: Now it's Christopher.

Kurtzer: It's Christopher, yes.

Cohen-Almagor: Because there were elections.

Kurtzer: $\quad$ Yes. The new administration came in on January $20^{\text {th }}$ of '93.

Cohen-Almagor: And you stayed in the same position.

Kurtzer: I stayed in the same position, yes.

Cohen-Almagor: And then it all came about in September.

Kurtzer: In mid-May, we were scheduled to have one of our multilateral working group meetings on refugees in Norway. I was the Chair of that group and was supposed to go, but I could not travel to the meeting. Edmund Hull, who was on the National Security Council staff, ${ }^{15}$ and who was part of our peace team and, therefore, aware of what was going on, went in my place, as the Chair of the delegation. Something happened, as soon as he arrived, that made the Norwegians nervous. I think he went up to Egeland or one of the Norwegians, in the hotel lobby, and said, "Let's have a talk about what's going on in the

\footnotetext{
13 Yair Hirschfeld, Track-Two Diplomacy toward an Israeli-Palestinian Solution 1978-2014 (Washington DC, 2014).

${ }^{14}$ Warren Christopher was US Secretary of State between 1993 and 1997.

${ }^{15}$ Edmund J. Hull, http://www.nndb.com/people/660/000122294/
} 
secret channel." If that's what happened, it was a mistake for two reasons. Number one, you don't talk about the secret channel in a hotel lobby. Number two, the Norwegians didn't know him and, therefore, didn't know that he was part of the team that would have been briefed on the issue. At the same time that that was happening, the transition took place, on the Israeli side to government officials -- Uri Savir ${ }^{16}$ and Joel Singer. ${ }^{17}$ At that point, Peres - for whom there was always a bit of distrust of the United States in the peace process made it clear that he didn't want the briefings to continue.

So, as we say in our idiom, we "went dark" then, from May until the end of July. We didn't know what was going on. We were curious, but it was also a period of extremely intense activity in Washington on the Palestinian track.

\section{Cohen-Almagor: Because there were the Washington talks.}

Kurtzer:

We had the Washington talks, and Aaron Miller ${ }^{18}$ and I were deputized to work with the Palestinians and the Israelis. We were working on a Declaration of Principles. And we stayed "dark" until the end of July, when Christopher traveled to the region. When we arrived in Israel on July 31, Yossi Beilin asked to meet me late one night, and he spent about two and a half hours basically laying out the whole emerging Oslo agreement. There were still a few minor things to be done, but he gave a briefing that indicated they had done 99\%. They had not yet finished the language on mutual recognition, which was a big issue. Christopher was scheduled to meet Rabin very early the next morning. Beilin's briefing finished after midnight, and it made no sense to write a memo summarizing the briefing. So, in the early morning pre-brief of Christopher I said to him, "Let me just give you a very short summary of what happened last night." When I concluded, he asked what he was supposed to do with this information. Our group suggested that, in the small meeting with Rabin, he should ask Rabin, "This is what we were briefed on. Are you ready to say yes?" Well, as it turned out, he didn't ask that question. He asked a different question: "We got a briefing. Do you think Arafat's going to go through with this?" Rabin had a very negative view of Arafat, as we know -- had never trusted him, even though he understood that Arafat was the ultimate Palestinian decision maker. Rabin's answer to the question was analytical. He basically said, "I don't think Arafat's going

${ }^{16}$ Director-General of the Foreign Ministry (1993-1996).

17 See R. Cohen-Almagor, "The Oslo Peace Process: Interview with Joel Singer", Israel Affairs (August 24, 2018).

18 See Miller, The Much Too Promised Land: America's Elusive Search for Arab-Israeli Peace (New York, 2008). 
to go through with it." The problem was Rabin was answering the wrong question. The question Christopher should have asked was whether Rabin would go through with it. As I learned later, it was at this meeting with Rabin that he handed to Christopher and Ross the so-called "deposit" or the "pocket" on Golan. He gave to Christopher and Ross a diplomatic gift, that is, Israel would be ready to meet Assad's requirements on territory, if Assad would be ready to meet Israel's requirements on security and peace.

Christopher returned to the hotel after his meetings, told us what Rabin had said (in response to the wrong question), and he and the rest of the peace team dismissed the Oslo channel. Thus, they were surprised when Peres showed up at Point Magu in California and said an agreement had been reached.

Cohen-Almagor: What do you know about Abu Ala? Because, to the Israelis, as far as I can understand, he was almost an unknown entity in 1992.

Kurtzer:

We didn't know him. He was also an unknown entity to us. We had some intelligence community analysis of Palestinian finances and economics, and he was, of course, the head of the business side of the PLO. So, we knew a little bit about what he had been doing, but nobody knew him.

Cohen-Almagor: What are Oslo's achievements, in hindsight, if you reflect. What do you think the main achievements of Oslo were? Was it a bad agreement? Was it a viable agreement? Was it a mistake? Was it a win? Was it an achievement? What was it?

Kurtzer:

The single biggest achievement was to fix the problem of Palestinian representation that had hampered us before that moment.

Cohen-Almagor: $\quad$ You mean negotiating directly with the PLO.

Kurtzer:

The PLO is the body that's been approved by the Palestinian people to represent them. For years, Israel and we had tried to circumvent the PLO -- the Village Leagues, or Shamir's election plan, or even the Madrid Peace Conference, with the joint Palestinian-Jordanian delegation. There were efforts to try to get around the PLO, but it had never worked. Rabin understood this. He came to Washington in February 1993, for his first visit.

Rabin held a meeting with only us, the lower level officials, not including Christopher. He engaged in a thought process, that he was speaking out loud, where he said, "Arafat's not 
Cohen-Almagor:

Kurtzer: acceptable to me. He's a terrorist. He kills people. I don't trust him at all. But I can't negotiate with the Palestinian delegation in Washington, because (a) they don't have any authority, and (b) they turn to Arafat anyway. And so, how can I get around this without talking to Arafat?" He kept coming back to the reality of what he had to deal with, but didn't want to deal with. So, even if he didn't know about Oslo from the very beginning, when Peres finally told him about Oslo, he was in a frame of mind to understand its importance. And that is the single biggest achievement of Oslo. The Oslo Declaration of Principles has tremendous weaknesses. It was weaker, much weaker, than the DoP that we were negotiating in Washington. And Rabin knew that.

\section{Elucidate. Weaker. What does that mean?}

In June of '93, Aaron Miller and I drafted a compromise text, because the two sides had been exchanging language and so forth. And there were several issues that made Rabin extremely angry in that U.S. draft. One was jurisdiction over land. The Palestinians said they would not accept the idea of personal autonomy - which had been around since the first Camp David. So, the provisional authority had to have jurisdiction over land, in their view. Rabin was not ready yet to give that up. I can't remember the formulation, but we had a Jerusalem issue in there. The other big issue was legislation, legislative authority. The Israeli position, since the autonomy talks had started in 1979, was that the Palestinian Authority would have the ability to promulgate regulations, but not to legislate. Legislation is a manifestation of sovereignty. Our draft said they would have the right to legislate. We had some caveats in there, so that they couldn't legislate an independent state or declare independence. When Rabin saw our draft by that time, he already had in front of him what was going on in Oslo -- he understood that our draft was much, much further down the line.

But that was the weakness of Oslo, that it didn't have those things in it. The Israeli negotiators, later, were to admit, as we understood at the time, that the five-year period that was supposed to end in May of '99 had no definition. Oslo didn't say that the outcome of the final status negotiation would be an independent state. It just said there should be a final status agreement. A breakthrough moment existed in '93 to definitively declare the two-state outcome -- that five years after the first implementation agreement in May '94, there would be a Palestinian state. And that was missing.

Also missing was any reference to settlements and any reference to Jerusalem. You remember, in Oslo, the lastminute hitch was the requirement that Holst, the Foreign 
Minister, send a letter that Jerusalem will be handled in final status - it wasn't in the agreement itself.

And there was no mention of settlements at all. The Israelis have said that the reason settlements weren't mentioned is that Rabin had allowed them to say, as a verbal commitment, that he was going to constrain settlement activity, but couldn't take the political step of putting it in writing in the agreement, because there would be too much of an uproar. So, it was kind of a "trust me" moment. And they conveyed that to the Palestinians, and Arafat accepted to trust Rabin on settlements. On the one hand, Rabin never authorized another formal settlement. But on the other hand, settlements grew, both in terms of the unauthorized, illegal outposts and in terms of population.

Cohen-Almagor: So, when you saw the agreement, you already had your suspicions. You said it's a good, positive step along the way to peace, but it's far from perfect. You knew that -

Kurtzer:

We knew that it was far from perfect, but it was a political breakthrough. I guess I should have started with that. I mean, it was sensational in that respect. The White House ceremony was amazing. And that iconic picture of Clinton presiding over the handshake. So, at that point, who's going to look at the text? Only us nerds. But, politically, it was explosive, as you know.

Cohen-Almagor: What do you think the Norwegian role was in this?

Kurtzer:

Well, the most positive thing they did was to get this thing off the ground. And that meant being sensitive enough to the constraints that were much more significant on the Israeli side. In the beginning, you had an official on the PLO side negotiating with two academics. I talked to Yair Hirschfeld about this, because it was uneven. But the Norwegians were sensitive to that. Number two, they were good "caterers", in the sense that they set up the meeting well. They provided auspices, they made people feel comfortable. In the negotiations, the importance of socializing the two sides to each other should not be underestimated. Israel and the Palestinians are enemies, but Israelis and Palestinians know each other in the West Bank and Israel. Nobody knew the PLO. Sometimes, a couple of Israelis would run off and see them somewhere, but the PLO was like a locked room, as far as anybody was concerned. Nobody knew who they were or what they were. And thus the socialization process was quite important. I'm not aware that the Norwegians did anything more substantive, but I don't want to underestimate the role they played. 
Cohen-Almagor: So, they were not mediators, they were facilitators.

Kurtzer: $\quad$ They were definitely facilitators, definitely not mediators. Even if, once in a while, they may have suggested something. But I don't even think they did that very often.

Cohen-Almagor: Do you think that the absence of the United States was an advantage or a disadvantage?

Kurtzer: $\quad$ I think, given the timing of when this happened, the absence of the United States was an advantage. It was a new administration, trying to get its feet on the ground. There was a certain amount of suspicion on the part of the new Clinton administration that the Bush administration had been too tough on Israel. And so, being asked to get involved in a PLO thing, I think, would not have helped. It was very wise that the Israelis and Norwegians kept us briefed, at least most of the time.

That said, what we also understood all along, until the end, is that when he did know about Oslo, Rabin's conception of Oslo was that it would feed into the Washington talks. And it turned out that that didn't happen at all. Oslo became an independent initiative.

Cohen-Almagor: Do you think that there is a role for small countries to play in mediation? Or just facilitation, like what happened in Oslo?

Kurtzer: $\quad$ Norway has had successes and failures. They had a major failure in Sri Lanka. ${ }^{19}$ They took a decision, once they became an oil producing giant to use a multibillion dollar fund for the future. They took an affirmative decision that they were going to become a country that would do mediation. Sometimes it works, sometimes it doesn't. Sometimes a conflict can benefit from what they offer. And sometimes, as in Sri Lanka, you need somebody to come in and knock heads a little bit, which the Norwegians don't have the power to do.

Cohen-Almagor: So, if I understand you correctly, you are saying that they have the role as facilitators, but not as mediators.

Kurtzer: I think it gets more challenging to think of them as mediators.

\footnotetext{
19 "Norway in Sri Lanka - The peace initiative that went out the window", UN Information Centre for Western Europe, https://www.unric.org/en/sri-lanka/27121-norway-in-sri-lanka-thepeace-initiative-that-went-out-the-window
} 
Cohen-Almagor: Is it possible to have a deal without the United States?

Kurtzer: $\quad$ Sure. If Israel and the PLO really want a deal, they don't need the United States. The problem is that they have gotten to a point of not being able to figure out how to build a bridge between the last positions of the two sides. And that's the role that somebody's got to play. Is it possible for them to do it themselves? Sure. If you look at what Olmert offered in 2008, in a strictly bilateral negotiation, Olmert offered almost everything, but not everything. ${ }^{20}$ The question: Had he not been indicted, or was not heading towards an indictment, would he have understood that to really test the Palestinians you have to offer everything? Because what do they have? They don't have anything to offer. They're going to get territory. They're going to get some number of refugees, even if you call them humanitarian family reunification. They're going to get something in Jerusalem, which they're going to call a capital. What do they give, besides a commitment to make peace?

Cohen-Almagor: You stop terror. That's a big deal.

Kurtzer:

Yes. it's a huge deal, but it's a hard problem for Israel because you're giving very tangible assets in return for a commitment.

Cohen-Almagor: Let's talk about Camp David. Were you there?

Kurtzer:

I was not there.

I thought that I should have been, but I was ambassador in Cairo, and the Egyptians didn't want to go to Camp David, and so the administration didn't invite the American ambassador to Camp David.

I went to Cairo in January of '98, and was there until the summer of 2001, when I transferred to Israel as ambassador.

The U.S. team at Camp David also didn't keep us briefed. Didn't keep me and Bill Burns, who was in Jordan, ${ }^{21}$ briefed on what was happening, which meant that we couldn't keep our host governments briefed. Mubarak was fuming angry that he was getting phone calls from the Palestinians and the Israelis, and I had nothing to say to him. I didn't know what was going on. I called Camp David, tried to get through to people. Nobody returned my calls. I think this is one of the main faults of American diplomacy. You get into this insular thing, where you don't realize that you can use the Egyptians,

20 Ehud Olmert, In First Person (Tel Aviv, 2018) [Hebrew].

21 William J. Burns was the American ambassador to Jordan from 1998 to 2001. http://carnegieendowment.org/experts/1014 
or you can use the Jordanians. But if you do that, you have to invest some time with them. I did get one call from Dennis Ross, in the middle of one night, while he was in Camp David. He said to me to go to Mubarak and propose the "upstairs downstairs" idea on the Temple Mount, Haram al-Sharif. The U.S. had a proposal on the table that Palestinians would enjoy sovereignty on the top of the Haram, and Israel would enjoy sovereignty below the surface. So, I said to Dennis at the time, "Number one, I think it's a pretty silly idea. And number two, are you sure that there is a possibility that either side is going to accept this?" He said, "Yes. We're working it, we're working it." So, next morning, I called Mubarak. He was in Alexandria, and I asked if I could come see him. And he said, "No, we'll just talk on the phone." I said, "I got this phone call from Camp David and this idea, and you know, we'd like your support, if you could call Arafat." And his anger came out, because he said, "I've heard this already from the Palestinians, who think it's a really bad idea. And l've heard from the Israelis, who think it's a bad idea. And now you're telling me, as though this is a brand new idea." He was really angry. And, of course, he was right. We had kept him shut out for however many days, eight or nine days at that point.

Cohen-Almagor: So, this is one thing that could have been done differently. To involve Mubarak, and maybe the Jordanians, and the Saudis.

Kurtzer:

And the Jordanians, and the Saudis. Yes, of course.

Cohen-Almagor: Could anything else have been done differently at Camp David?

Kurtzer:

Well, a lot of things. If you look at the first Camp David, you have two states; they have a structure and a history, and all the rest. Which you don't have at Camp David II. You have a state that's occupying a people, that's asking that people to negotiate its way out of occupation. One of the things that marked the first Camp David is that there were already drafts of what would emerge as the Camp David Accords circulating before Camp David. The U.S. and the Egyptians and the Israelis met at Leeds Castle in the United Kingdom, ${ }^{22}$ and the U.S. produced a draft based on those talks. So, Carter made the political decision to convene a summit, which is not easy to do. But he did it on the basis of there being some raw material that had been worked on, and minimum terms of reference. In the second Camp David, there was no such

\footnotetext{
22 Association for Diplomatic Studies and Training, "Far from the Madding Crowd - Leeds Castle and the Road to Camp David", https://adst.org/2016/08/far-from-the-madding-crowdleeds-castle-and-the-road-to-camp-david/
} 
thing.

Cohen-Almagor: There's no paper.

Kurtzer:

There's no paper discussed in advance. There's no agreed concept, even. Arafat didn't want to go to Camp David. I got a call before Camp David from Washington that asked me to see Mubarak and ask him to put pressure on Arafat to come to Camp David. So, I go to see Mubarak. We talk about it and he says, "All right, l'll talk to Arafat." He comes back to me and he says, "Arafat said two things in response to the request or the demand that he go to Camp David. Number one, why should he go to Camp David when there are secret talks underway in Stockholm that are not yet ripe? And secondly, he's afraid that there'll be a U.S. paper that he hasn't seen, and that, as a result, if he doesn't say yes to it, he's going to get blamed for failure." So, I report this to Washington. My answer to Mubarak from Washington is, "You can tell Arafat he's not going to be surprised by a U.S. paper and he won't get blamed." As it turned out, we surprised him with a U.S. paper and he got blamed.

Cohen-Almagor: $\quad$ So there was a paper during Camp David. After a few days. I think, four days, or the fourth day. It's Miller and Ross -

Kurtzer:

Yes. Which Arafat had not seen before.

Cohen-Almagor: Which the Israelis corrected.

Kurtzer:

Which the Israelis corrected, and the Americans handed over the corrected copy. So even if they had retyped that page, which should have been the minimum they did, was it the right tactic to give Yasser Arafat a paper at that early stage?

Cohen-Almagor: The Israelis and the Palestinians rejected the paper.

Kurtzer:

Because, as I understand it, Barak always got cold feet. He got to a point at Camp David where he and Arafat stopped talking to each other. They didn't meet after the first day or two.

Cohen-Almagor: I don't think they ever met. Not substantially.

Kurtzer:

Well, there was, I guess, one trilateral right at the beginning. Remember that picture of Barak pushing Arafat through the door? So, I don't take anything away from Barak for having made some offers at Camp David that were quite forward leaning. But the tactical and negotiating mistakes at Camp David were extraordinary. And I'm talking primarily about the 
American side.

Cohen-Almagor: Why did the Americans agree to it? If Yasser Arafat tells you, we are not ready. And I think one of the American negotiators said the time is not ripe. So why did Clinton agree to it? I understand Barak pressured him -

Kurtzer:

I don't know if one of the negotiators said it. Maybe yes, maybe no. Clinton at this point, was heavily invested in the peace process. He spent six years largely uninvolved, and then at Wye Plantation he got overly involved. He went from zero to a hundred. So, by the time Barak approached him, and said, "I want to do a summit to try to either solve this thing or unmask Arafat", Clinton was so heavily involved, invested, that it probably made sense to him. He had six months left in his administration. Maybe, he said, if Carter could do it at a summit, I can do it at a summit.

Cohen-Almagor: So why didn't it work out? He was there. He was heavily involved. He even attended meetings. Why didn't it work out?

Kurtzer:

Arafat wasn't ready to reach any agreements at Camp David. I think Arafat would have been happy to conclude Camp David with an agreement to meet again, but Arafat was not ready to reach any substantive agreements. Barak showed up at Camp David without a government, basically. It was a minority cabinet. Arafat knew Israeli politics as well as we did. So, he's looking at, essentially, a very weak prime minister. He's looking at a president who's only got six months left. And I think he was also scared of his own constituency - refugees, in particular, and the Arab world -- on the question of Jerusalem. So, I think Arafat did not go to Camp David with an intention to reach any agreements. The best that could have been gotten out of Arafat was to have a process continue. Maybe another summit in September, and then another summit in October, and then a closing summit that wraps things up before the administration leaves office. He was not prepared to reach an agreement.

Cohen-Almagor: So, you say that even if Barak would propose to him what he wanted -

Kurtzer:

Barak, as I mentioned, went further than any previous prime minister on substance. But it wasn't close to Palestinian requirements. If you really want to test the Palestinians, you've got to offer them $100 \%$ of what they want. That's not the way negotiations normally take place. Except, it goes back to the issue of negotiating apples and oranges here. The Palestinians want $100 \%$ of the $22 \%$ of the land that's left for 


\section{Cohen-Almagor: How do you know that?}

Kurtzer:

Cohen-Almagor: What were the American mistakes at Camp David? Besides the one that you already mentioned.

Kurtzer:

I was the head of the refugee working group, as early as 1992. And the refugees came into that group as part of the Palestinian delegation, and they all said to us - and I don't want to say that I believe them - "Look, we're not unrealistic people. You've got some people sitting with the key to their former homes around their necks. They're sitting in a refugee camp in Lebanon. They expect that we will produce their house in Akko [Acre] or in Ramla. But most Palestinians have no expectations. They want dignity. They want a sense that they didn't lose out in history. That there is a right and wrong here." These are issues that I don't know how to resolve; the refugee issue is challenging, in that respect. And that's why I'm not sure you can get to $100 \%$ of what the Palestinians need on refugees. You can, on almost every other issue. But that's really the only way to finally test whether the Palestinians are really ready to make peace. And I have to tell you, I don't know if their answer would be yes, under those circumstances. If Olmert, in 2008, after putting his proposal out had come back to Abbas and said, "Okay, look, I know what you want. Here it is." And then laid it all out? I don't know the answer to it. But what I do believe - I can't say I know it but I believe that you will not ever be able to answer that question definitively until you've reached that $100 \%$ point. So, this idea that you can do $97 \%$ and $98 \%$, and you can finagle and maneuver -- it's not going to work with a people that has had problems of leadership and organization and structure and process. Palestinians don't work that way. It's not going to happen.

Lack of any preparation that would have been concretized either in a paper or even a conceptual understanding -- kind of, where the Americans wanted them to be. We call them parameters now. In other words, we tell the parties you can't go to Camp David with one side saying, "I want all of Palestine," And the other side saying "I want all of Eretz Yisrael [the Land of Israel]." Rather, the Americans say, "that doesn't work. We're talking about the '67 lines with mutually- 
agreed changes." But there were no conceptual understandings, let alone a paper. Number two, my understanding is that we didn't always have the right people there on some of the core issues. On Jerusalem, for example, we didn't have anybody who really understood Jerusalem. Each of these issues requires a significant amount of technical expertise. The technicians are not going to make the deal, but the devil is in the details. So, if you're a senior official, you want to go into the room knowing that the guy right behind you knows exactly what the Green Line is, and where the neighborhoods are, and how many people are living in various settlements or neighborhoods. You don't have to know that, but you have to know that you can lean back, when those issues come up, and get a briefing. And we didn't have all the right people there who knew that stuff. If you have the right people on the core issues, and some different or unanticipated issue comes up - offshore gas, which nobody was even thinking about -- then you can say, "All right, look, we didn't anticipate that offshore gas would come up. I'm going to call back to Washington and get our energy experts here."

Cohen-Almagor: What's the relationship between Barak and Albright ${ }^{23}$ ?

Kurtzer: $\quad$ You know, I really don't know, because I wasn't there.

Early on, in Albright's tenure, I went off to Egypt, so my focus was Albright's relationship with Mubarak and with Amr Moussa. ${ }^{24}$

Cohen-Almagor: Was it correct to put all the blame on Yasser Arafat in the end?

Kurtzer: No, of course not. Even if I would agree that he bears the lion's share of responsibility for failure, once you assign blame, you're basically saying the process is over. Or has reached a point where it can't go further. What you want to do at the end of a failed Camp David is to put out the idea that you've narrowed some differences, and there are problems that remain, and the two sides are going to go back, and they're going to consult, and we'll have our team come out for further talks. You know, you want a sense of continuity. This could have happened. Right after Camp David, Ned Walker, who was then the Assistant Secretary of State, made a trip to the region to brief on Camp David. He came to Egypt, met

23 U.S. Secretary of State 1997-2001. https://www.britannica.com/biography/MadeleineAlbright

${ }^{24}$ Amr Moussa was the 6th Secretary General of the League of Arab States (2001-2011). 
Cohen-Almagor:

Kurtzer:

Cohen-Almagor: Is it a problem?

Kurtzer:

Cohen-Almagor:

Kurtzer:

Cohen-Almagor:

No.

Yes, of course. with Mubarak and the briefing was pretty negative. Mubarak said to him - even though Mubarak, you remember was angry - Mubarak said to him, "Don't pull the plug. It's not over. You had discussions, they didn't work, but nobody ended the process at Camp David, so don't you end it." Mubarak was now cheerleading for the American side not to give this thing up. And he was right. In fact, that summer, there were a lot of intensive discussions that went on, which could have resulted in the paper that Clinton put out six months later, but it didn't.

So, the alternative to blaming Arafat publicly would have been to do it privately. Send your envoy out to Arafat and say, "You should have done better here." But once you blame him publicly, what does he take back to his own people?

Is the United States a fair broker in negotiations?

It's only a problem when the U.S. bends too far. Aaron Miller, in his book, called the United States "Israel's lawyer", which meant we were bending over too far. When the Palestinians say that they were hearing things directly from the Israelis, and then they would hear the same things from us, but only worse - what were we doing? Why were we pretending to be a mediator? In the '90s, and I don't think it exists today, but in the '90s, you could still say that our relationship with Israel was actually an asset, because there was a belief that we could use that relationship to help Israel take hard decisions by providing a soft landing, safety net, off-the-table benefits, more assistance, security, whatever. In the '90s, I think that was valid. But it's only valid if you don't go overboard with it. Because you run the risk of going overboard by feeding Israel, without their doing anything. In other words, you feed Israel when they take the risk for peace. But if you feed Israel and they're not taking the risk for peace, why is there an incentive for any Israeli government to take a risk? If I were an Israeli prime minister, why would I do anything, when the Americans are going to give me what I want anyway? Somewhere along the line, we became less useful as a mediator.

Could the United States have put more pressure on Arafat and Barak at Camp David?

And would it be prudent to put more pressure on them? Is it the part of a mediator to do that? 
Kurtzer:

A mediator has to decide whether it has the power and the influence and the staying power to do it. In other words, you can make threats, but then, are you going to actually carry through with the threats? We have the flip side of putting pressure, which is incentives, big packages. Look back at Kissinger $^{25}$ in '75, when we had a crisis with Israel over the second Sinai disengagement accord. Rabin ended up agreeing to the exact package that he had not agreed with four months earlier, because we put an enormous amount of pressure and incentives on the table that gave Rabin the reason and the ability to say yes. That's the role the United States can play. The question is whether we are ready to put a little pressure on? I don't know the answer to that.

How many statements have we made since 1967 that we think settlements are an impediment to peace? Why would anybody listen to us anymore? Yesterday the State Department said this. Two weeks ago, they said it. It doesn't mean anything. The one time when we actually took action, Israel changed. It was Shamir and loan guarantees, back in 1991. He wanted loan guarantees for the immigrants. We helped secure the freedom of those immigrants, so it was in our interest to help them get absorbed. We simply didn't want them settled in the occupied territories. We said that to Shamir. He said, "They're going to settle wherever they want to settle." Then we said, "We're not going to give you the guarantees." And it helped persuade Shamir to buy into Madrid in August, which he had turned down in June.

Cohen-Almagor: The Arab Initiative, 2002, what do you think about that? Was that something you worked on?

Kurtzer: $\quad$ We heard about the Tom Friedman-Crown Prince Abdullah conversations. ${ }^{26}$ It was also at a time when Cheney was visiting the region. It was his first and only trip. But Cheney was not interested. ${ }^{27}$

Cohen-Almagor: Why?

\footnotetext{
${ }^{25}$ Henry Kissinger was President Richard Nixon's National Security Advisor (1969-1975) and Secretary of State (1973-1977). https://www.biography.com/people/henry-kissinger9366016

26 "Thomas Friedman announces the Saudi Peace Initiative" (February 17, 2002), http://www.mideastweb.org/saudipeace_friedman.htm

${ }^{27}$ Richard Bruce Cheney was the 46th Vice President of the United States (2001-2009) in the President George W. Bush administration, and Secretary of Defense (1989-1993) in President George W.H. Bush administration.
} 
Kurtzer:

I don't think he bought the idea at all. He was very sympathetic to Sharon's dilemma with the Intifada. And, most important, it was the worst month of the Intifada. It was the month just before Pesach [Passover]. Every other day, fifteen Israelis were being killed. There was no stomach to think about these things. So, there was a moment when Arafat wanted to go to the Arab summit and Sharon said, "Sure, you can go, but you can't come back." And then Sharon said, "Actually, if you want to go, l'll go with you, if I'm invited." It was all seen as not very serious. So, the timing in 2002 was a killer, but that doesn't explain why five years later, in Riyadh, when they reaffirmed the Arab Peace Initiative, it also just fell dead, without any response.

I co-authored an op-ed in the International Herald Tribune with Rosemary Hollis just before the 2007 Arab summit, where we knew they were going to reaffirm the Initiative. ${ }^{28}$ And the point of the op-ed was to say, don't miss a second opportunity. The idea was the U.S. should immediately welcome it, and immediately invite the Quartet, the Arab Quartet ${ }^{29}$ and the parties to Washington. Just get them there and start working on it.

Cohen-Almagor: Nobody picked it up?

Kurtzer: No.

Cohen-Almagor: Okay. Gaza. Was it the right thing to evacuate Gaza? For the Israelis?

Kurtzer: $\quad$ As a political move, it was extraordinary. As a political move by the man who put the settlers in Gaza in the first place, it's even more extraordinary. Three things I would say in answer to your question. Number one, I actually think Sharon was ready to move beyond Gaza, had it succeeded. Number two, I think Arafat, when it first came out, in December of 2003 and later, made a fundamental strategic error by not pocketing it and doing something. And number three, Sharon made a tactical mistake by keeping it unilateral until near the very end, when he then opened up the idea that we have to coordinate. It's not that he was responsible for what happened afterwards, but the Palestinians were given an easy excuse. "You know, we don't even know where the key to the men's room is."

28 Daniel Kurtzer and Rosemary Hollis, "An Arab Initiative That Can Work", International Herald Tribune, March 21, 2007 http://www.nytimes.com/2007/03/21/opinion/21ihtedhollis.4978404.html? r=0

${ }^{29}$ Saudi Arabia, UAE, Bahrain and Egypt. 
Cohen-Almagor:

Kurtzer:

Cohen-Almagor:

Kurtzer:

Cohen-Almagor: You think it was a mistake to allow them to run?

Kurtzer: That's what you think? apartments. was a good idea? here, in Princeton, and I wasn't shocked.
Israel walked out of the place after occupying it for 38 years. I think it was a very bad tactical mistake. I know that there were Israeli officials we were dealing with at the time who agreed that it was a tactical mistake, but they had their instructions, and the instructions were not to negotiate the evacuation with the Palestinians.

So, to do it was right, but the way of doing it was wrong?

Yes. And number four would be not preparing the ground for the settlers who were evacuated. A lot of them didn't want the ground prepared. They didn't want to move into readymade

And allowing Hamas to participate in the elections in 2006

I was already out of government at that point. I had left right after the disengagement. U.S. thinking at the time was that anybody who participates has to meet certain criteria. In other words, we didn't talk about Hamas or not Hamas. But everybody has to commit to peace and no violence. Which, obviously, would either rule out Hamas, or would reflect a change in Hamas. Three months later, before the turnover, I was visiting Israel and it was clear that U.S. policy had changed, that we were encouraging the election and not establishing preconditions. I think a lot of that had to do with a very bad assessment on the part of both U.S. and Israeli intelligence that the PLO was going to win the election. I saw a well-known Palestinian pollster ${ }^{30}$ during that trip and asked "What's going to happen?" And he said, "Hamas is going to do very well." He maintained, "I don't know what the numbers are, but they're going to do very, very well." It was not that they were so popular; it was that the PLO was so unpopular and corrupt. Condi Rice wrote in her book that she woke up on election day in Palestine and was "shocked" that the Hamas had won the election. ${ }^{31}$ I wasn't shocked. I was sitting

Of course. If, if the Palestinian Authority was an advanced democracy, then years before, we would have argued that

\footnotetext{
${ }^{30}$ Khalil Shikaki, http://www.pcpsr.org/en/node/192

31 Condoleezza Rice served as the United States' National Security Adviser (2001-2005), and as U.S. Secretary of State (2005-2009). She is the author of No Higher Honor (NY, 2011).
} 
Cohen-Almagor:

Kurtzer:

Cohen-Almagor:

Kurtzer:

Cohen-Almagor:

Kurtzer:

Cohen-Almagor:

Kurtzer:

32 Truce or armistice. everybody should be allowed to participate. We're talking about stability. We're talking about a people, a non-sovereign, occupied people. So, there have to be measures to limit problems. Hamas is a problem.

How do you deal with that?

Well, I thought the idea was to establish fair conditions. We used to have them in the United States during the period of the Soviet Union, that you had to sign, when you registered to vote, that you were not a member of the Communist Party. But it's an acceptable part of democracy to have certain conditions. Hamas candidates should have been expected to declare that they accepted the agreements into which the PLO had entered. Which means they would have accepted Oslo, basically.

How do you deal today with Hamas? First of all, Israel wants security. The Israelis are saying, if we're going to have peace without security, we'd rather have security without peace. How do you deal with this issue?

One way is to consider a long term hudna ${ }^{32}$ The argument would be that they're not ready for peace with Israel. Israel is not ready for peace with them. They want to destroy each other, but they both have an interest not to fight all the time, so they work out red lines, for example, Hamas won't fire rockets, Israel will lift the siege a little bit. Maybe they will be allowed to build a port under international supervision. Such agreements don't require one side to recognize the other.

Can that be accepted by Hamas?

I think Hamas has basically accepted it since 2007. The red lines have been crossed sometimes. They've been blurred. If there's a possibility of a red line agreement working, or an informal hudna working, it has to be more clearly understood by the two sides. You may need a third party. Maybe not the United States, but Egypt or Qatar or somebody to really get a clear understanding that's not going to be committed to paper. That's one possibility.

Does the United States speak to Hamas?

No. That's why I'm saying that it won't be the United States that will do that. The second possibility is to let Hamas and Fatah reconcile. Don't stand in their way, which we and Israel 
both do. We've made clear we don't want that to happen. Let them reconcile. And instead of requiring Hamas to accept the international conditions of recognizing Israel and renouncing terrorism, impose those conditions on the government that follows. In other words, tell them that we will not deal with a Palestinian Authority which has abandoned recognition of Israel, renunciation of terrorism and so forth. So that any Hamas person who joins that government will be working according to those conditions.

Cohen-Almagor: Hamas is in the government, but it's a technical government, a specialist government. Without adhering to the guidelines, still, Hamas is there. That's the way they play this issue.

Kurtzer:

I would deal with Hamas through a back door. Have them get their toes wet a little bit. Have them take some responsibility within the context of a unified government.

Cohen-Almagor: Back door between Israel and the Hamas?

Kurtzer:

No, a back door to the three conditions.

Cohen-Almagor: What are the three conditions?

Kurtzer:

Recognizing Israel's right to exist, renunciation of terrorism and accepting agreements that have already been entered into, meaning Oslo. The U.S. position is that until Hamas does those things, we won't deal with Hamas. Hamas is not going to do those things first. But, if you walk them through a back door, where they're entering into a government that does agree with those principles, and you deal with that government - you've gotten them "a little bit pregnant".

\section{Conclusion}

Oslo was a breakthrough. For the first time, Israelis and official representatives of the Palestine Liberation Organization sat with each other to talk peace. Until then, Israel refused to recognize the PLO. Israeli leaders invented Palestinian representatives that were mere strawmen, and strawmen are just that, strawmen. They did not represent the Palestinians. They served Israeli interests, and consequently, were unable to deliver. For Kurtzer, this was the single most important achievement of Oslo. Israel and the PLO negotiated directly.

Oslo, however, was not detailed enough. Major issues were ignored, which led to the failure of the implementation of the agreement. Simultaneously, Kurtzer and his colleagues were drafting a more comprehensive text that included contentious issue such as Jerusalem, the 
settlements, jurisdiction and final status. Kurtzer had in mind a two-state solution, whereas Rabin had in mind Palestinian autonomy, a framework that would not have satisfied the Palestinians. Oslo was based on the 1978 Camp David Accords and there, the negotiations revolved around Palestinian autonomy.

An interesting question is why the Washington delegation acted in accordance with a very different set of instructions than those followed in Oslo, and why the Oslo delegation had more freedom in the negotiations than the Washington delegation. The answer has to do with the buildup of the delegations and with the American presence only in Washington. While Rabin had closely monitored Washington, he came to know Oslo later in the game. Oslo was orchestrated first by Beilin, then by Peres and only later by Rabin. Beilin and Peres were willing to make concessions and to dictate an agenda that had a better chance to bear fruit. Rabin approved that agenda ex post factum. And secondly, as Kurtzer says, Washington scared Rabin, because the Americans were pushing him on substance and Rabin was holding back.

According to Kurtzer, Rabin's conception of Oslo was that it would feed into the Washington talks. This did not happen, arguably because Rabin wanted to progress slowly with the peace talks, and with peace-building. He wanted to see the fruits of Oslo before he made his next move. For Rabin, the security issue was essential; because he did not trust Arafat, caution was the name of the game. In a recent interview, Joel Singer said: "Every draft was seen and approved by him [Rabin] and I heard from him not once, not twice, not three times: 'It's all about security. I don't care about any other aspect of the Oslo agreement', he said. 'It's all about security. If there is security, the agreement will succeed. If there is no security and it's otherwise perfect, the agreement will fail'." 33 The Oslo process failed not only because of waves of Palestinian terrorism that had swept Israel. At the same time, undoubtedly lack of security, including Rabin's personal security, played a major part in the failing Oslo saga.

Kurtzer thinks the absence of the United States served Oslo well. The Norwegians were good facilitators and they were well aware of their limitations. They were careful not to assume responsibilities that they would not be able to carry. The Norwegians could not press either side, and they knew it. They were unable to mediate between the two parties.

United States can mediate between the two sides. President Carter mediated successfully between Israel and Egypt and, as a result, the two countries signed a peace treaty. Camp David 2000, however, greatly differed from Camp David 1978, and Kurtzer voices his frustration. Unlike 1978, in 2000 there was no American paper to lead the negotiations, nor was there even an agreed concept. ${ }^{34}$ The Americans were ill-prepared for the summit. Arafat did not want to come to Camp David, and the gaps between Israel and the PLO were too wide to be bridged. Interestingly, Kurtzer does not think the U.S. needs to be a fair broker, so long as it does not bend too far.

${ }^{33}$ R. Cohen-Almagor, "The Oslo Peace Process: Interview with Joel Singer".

34 William Quandt, Peace Process (Berkeley, 2005). 
There are two important lessons for the future. First, the Americans should base negotiations on a paper requiring concessions from both sides, as was the case in the successful 1978 summit between Israel and Egypt. Without such a paper, there is no anchor on which to base the negotiations. ${ }^{35}$ In a follow-up to the interview, ${ }^{36}$ Kurtzer explains that a third-party mediator has choices to make about how much, whether and when to intervene in bilateral negotiations. Often, the third party will develop a paper that summarizes positions, lays out differences and suggests bridging positions. Alternatively, the third party can draft entire sections of an agreement and present them to the parties. In either case, the third party needs to do substantial work in advance, and must avoid putting forth a paper (a) where neither side is familiar with its concepts, or (b) that has been shared/coordinated with only one side. In Camp David 2000, Kurtzer thinks that the U.S. had not discussed the paper in advance in much detail, and then consulted only Israel in crafting what became the paper it put forward. The United States should have consulted with both sides in advance, and should have tried out formulas first, before committing them to a U.S. paper. Only then should the United States have shared the paper with both parties. Negotiating in good faith is a key for successful negotiations.

Second, there is a need to involve more Arab countries in the peace process. The Palestinians need them, especially in order to reach a viable agreement regarding the questions of Jerusalem, the Haram al-Sharif (the Temple Mount), and the refugee problem. The Israelis need them, as well, to support the process and resolve obstacles. Arab countries have important assets and abilities to move things in the right direction. To begin with, Egypt and Jordan, the two countries that have signed peace treaties with Israel and border on the conflict zones, should be involved. Saudi Arabia is also a possible partner at this stage, if its leaders are willing to play a constructive role, not only because of their personal interests vis-à-vis Iran, but because of their potential genuine will to bring the Israeli-Palestinian conflict to a close. Of course, such a dramatic change will have a major positive impact on the Middle East and beyond, and will serve nations that support peace and fight terror.

\footnotetext{
35 Interview with Aharon Barak (July 8, 2018); Jimmy Carter, Keeping Faith (London, 1982): 368-371; Stuart E. Eizenstat, President Carter: The White House Years (NY, 2018).

${ }^{36}$ Email on October 8, 2018.
} 